\title{
Intravascular hemolysis and the pathophysiology of sickle cell disease
}

\author{
Gregory J. Kato, ${ }^{1,2}$ Martin H. Steinberg, ${ }^{3}$ and Mark T. Gladwin ${ }^{1,4}$ \\ 1Pittsburgh Heart, Lung and Blood Vascular Medicine Institute and ²Division of Hematology and Oncology, University of Pittsburgh School of Medicine, Pittsburgh, Pennsylvania, USA. \\ ${ }^{3}$ Department of Medicine, Boston University School of Medicine, Boston, Massachusetts, USA. ${ }^{4}$ Division of Pulmonary, Allergy and Critical Care Medicine, \\ University of Pittsburgh School of Medicine, Pittsburgh, Pennsylvania, USA.
}

\begin{abstract}
Hemolysis is a fundamental feature of sickle cell anemia that contributes to its pathophysiology and phenotypic variability. Decompartmentalized hemoglobin, arginase 1, asymmetric dimethylarginine, and adenine nucleotides are all products of hemolysis that promote vasomotor dysfunction, proliferative vasculopathy, and a multitude of clinical complications of pulmonary and systemic vasculopathy, including pulmonary hypertension, leg ulcers, priapism, chronic kidney disease, and large-artery ischemic stroke. Nitric oxide (NO) is inactivated by cell-free hemoglobin in a dioxygenation reaction that also oxidizes hemoglobin to methemoglobin, a non-oxygen-binding form of hemoglobin that readily loses heme. Circulating hemoglobin and heme represent erythrocytic danger-associated molecular pattern (eDAMP) molecules, which activate the innate immune system and endothelium to an inflammatory, proadhesive state that promotes sickle vaso-occlusion and acute lung injury in murine models of sickle cell disease. Intravascular hemolysis can impair NO bioavailability and cause oxidative stress, altering redox balance and amplifying physiological processes that govern blood flow, hemostasis, inflammation, and angiogenesis. These pathological responses promote regional vasoconstriction and subsequent blood vessel remodeling. Thus, intravascular hemolysis represents an intrinsic mechanism for human vascular disease that manifests clinical complications in sickle cell disease and other chronic hereditary or acquired hemolytic anemias.
\end{abstract}

\section{Introduction}

Patients with sickle hemoglobinopathies have variable phenotypes, with different pain frequencies and severity and pleiotropic complications, including lung injury, stroke, cutaneous leg ulceration, kidney injury with proteinuria, osteonecrosis, and systemic and pulmonary hypertension $(\mathrm{PH})$. These phenotypes result from erythrocyte injury caused by sickle hemoglobin (HbS) and its deoxygenation-induced polymerization. Erythrocyte injury leads to extra- and intravascular hemolysis, endothelial dysfunction and vasculopathy, and occlusion of small and large blood vessels, producing tissue ischemia/reperfusion injury and inflammation. Damage to circulating erythrocytes occurs with wide diversity amongst individuals (1). This heterogeneity arises from differences in intrinsic characteristics of sickle erythrocytes, like heterocellular fetal hemoglobin ( $\mathrm{HbF}$ ) distribution, HbS concentration (2), hydration, and density $(3,4)$, and the cell's environmental transitions from macro- to microcirculation, laminar to turbulent

Conflict of interest: M.H. Steinberg has equity ownership of more than $\$ 10,000$ in publicly held companies in the health care field and has provided testimony as an expert witness in medical-legal cases. G.J. Kato is listed as a coinventor on a patent application by the NIH for the formulation of topical sodium nitrite (PCT/US2015/060015). M.T. Gladwin is listed as a coinventor on an NIH government patent for the use of nitrite salts in cardiovascular diseases (US 8,927,030 B2). M.T. Gladwin receives research support from Aires/Mast Therapeutics on the development of a phase II proof-of-concept trial using inhaled nitrite for pulmonary arterial hypertension and leads a collaborative research and development alliance with Bayer Pharmaceuticals. G.J. Kato and M.T. Gladwin receive research support from Bayer Pharmaceuticals.

Reference information: J Clin Invest. 2017;127(3):750-760.

https://doi.org/10.1172/JCI89741 flow, normoxia to hypoxia, isotonic to hypertonic environment, and acidotic to alkalotic milieu. Multiple components contribute to sickle hemoglobinopathy pathophysiology, including primary components arising from $\mathrm{HbS}$ polymerization and secondary components that are downstream effects of the HbS polymer. Understanding how these components' complexity is compounded by genetic and environmental modulation provides insight into the well-known clinical heterogeneity of sickle cell disease (SCD).

A cardinal feature of SCD pathogenesis involves inflammation, accompanied by heterocellular leukocyte-platelet-erythrocyte-endothelial adhesive events that trigger vaso-occlusive episodes, acute organ ischemia, and reperfusion injury. Twenty-five years ago, epidemiological studies identified leukocytosis, lower HbF levels, and higher total hemoglobin levels as risk factors associated with increasing incidence of acute painful episodes and acute chest syndrome (ACS) (5). The independent association of high total hemoglobin levels with more pain, ACS events, and osteonecrosis was never mechanistically explained; however, it was implied to be a result of increased blood viscosity (Table 1). Recent epidemiological studies found that lower hemoglobin levels and higher intensity of steady-state hemolytic anemia consistently associate with vasculopathic complications of disease, such as stroke, leg ulcers, $\mathrm{PH}$, priapism, and renal failure. This suggests that certain subphenotypes of SCD relate more to hemolytic anemia severity rather than sickle vaso-occlusion. The reader is referred to recent reviews describing the exceptional strides made in understanding the roles of red cell rigidity (6), inflammation, and cell adhesion in sickle vaso-occlusion (7-9). Here, we review the complementary role of intravascular hemolysis and anemia. 
Table 1. Subphenotypes of SCD and their association with hyperhemolysis, $\alpha$-thalassemia, and HbF

\begin{tabular}{lcc}
$\begin{array}{l}\text { Clinical features } \\
\text { Painful episodes/dactylitis }\end{array}$ & $\begin{array}{c}\text { Effect of hyperhemolytic subphenotype } \\
\text { Acute chest syndrome }\end{array}$ & $\begin{array}{c}\text { Effects of } \boldsymbol{\alpha} \text {-thalassemia } \\
\text { Increases risk }(151,152)\end{array}$ \\
$\begin{array}{l}\text { Leg ulcers } \\
\text { Osteonecrosis }\end{array}$ & Neutral $(42)$ & Increases risk $(152)$ \\
$\begin{array}{l}\text { Priapism } \\
\text { Renal function/albuminuria/hemoglobinuria } \\
\text { Stroke, increased TCD velocity }\end{array}$ & Reduces risk $(42,153)$ & Reduces risk $(42)$ \\
Bilirubinemia/cholelithiasis & Increases risk $(42)$ & Reduces risk $(71)$ \\
$\begin{array}{l}\text { Retinopathy } \\
\text { Sickle vasculopathy/TR velocity/ }\end{array}$ & Increases risk $(24,45)$ & Reduces risk $(24,43,165,164)$ \\
systemic hypertension & Increases risk $(23,42,170)$ & Reduces risk $(23,170-173)$ \\
Mortality & Increases risk $(178,179)$ & Reduces risk $(180,181)$ \\
\hline
\end{tabular}

Protective (189)

\author{
Protection by $\mathrm{HbF}$ \\ Protective $(5,32)$ \\ Protective $(31,32)$ \\ Equivocal $(21,153,154)$ \\ Equivocal $(22,157-161)$ \\ Not protective $(71,162)$ \\ Not protective (164-129) \\ Not protective in children; possibly \\ protective in adults (174-177) \\ Protective $(159,182)$ \\ Possibly protective (185) \\ Not protective $(19,49,62,68,187)$
}

Protective (190)

Hyperhemolysis is inferred from a combination of increased serum concentration of indirect bilirubin and lactate dehydrogenase. $\alpha$-Thalassemia was ascertained by gene analysis. For nearly every subphenotype it is possible to find some contradictory evidence because of differences in cohort age distributions, sample size, phenotype definitions, and analytical approaches. Because of space limitations, many studies are not included. For most subphenotypes, both children and adults are included. TCD, transcranial Doppler; TR, tricuspid regurgitant.

Unless specified, in this Review "hemolysis" and "intravascular hemolysis" are used interchangeably.

\section{The hemolysis hypothesis}

Nine years have passed since we proposed that intravascular destruction of sickle erythrocytes is pathogenetically related to certain common complications of SCD, igniting a long-smoldering debate on the mechanistic basis of these associations (10-12). The crux of the hypothesis was a general appreciation that products of intravascular hemolysis damage the vascular system (13). More specifically, it proposed that nitric oxide (NO) depletion in the microcirculation resulted from intravascular hemolysis-driven release of cell-free hemoglobin into the plasma that reacted with NO via the well-known dioxygenation reaction to form inert nitrate. This reaction occurs in vitro (14) and is promoted by blood substitutes in vivo (15), and its occurrence in SCD is supported by in vitro and in vivo evidence, summarized later in this Review (16). NO is a free radical produced enzymatically by a family of NO synthases (NOSs) during the conversion of arginine to citrulline. Endothelial NO, produced by endothelial NOS3, diffuses to adjacent smooth muscle, where it binds and activates the heme of soluble guanylate cyclase, which subsequently converts GTP to cGMP. This activation of cGMPdependent protein kinases produces vasodilation by causing calcium sequestration and perivascular smooth muscle relaxation. NO is also depleted during intravascular hemolysis when arginase is liberated from erythrocytes, destroying arginine, the substrate for NOS (17), and by reactions of NO with ROS that are generated during intravascular hemolysis. Compounding the effects of these NO- and arginine-scavenging pathways, lysed red cells release asymmetric dimethylarginine, an endogenous inhibitor of NOS (18). A role for intravascular hemolysis in promoting endothelial dysfunction was bolstered by epidemiological cohort studies linking laboratory biomarkers of the intensity of hemolytic anemia and risk of developing specific complications of SCD, including PH (19), cutaneous leg ulceration $(20,21)$, priapism $(22)$, stroke (23), and, recently, pro- teinuria and renal insufficiency (24-26). In contrast, as mentioned earlier, other complications were associated with lower hemolysis rates and higher steady-state hemoglobin levels, including the rate of vaso-occlusive painful episodes, ACS, and osteonecrosis (Table 1). Unlike hemolysis, traditional established risk factors for vaso-occlusive episodes, such as steady-state leukocytosis $(27,28)$ and high hemoglobin levels (29), do not accurately predict the above-mentioned vasculopathic events and mortality observed as the patient population ages. To date, no alternative mechanism has been proposed to explain the divergent associations between the severity of hemolytic anemia and specific clinical complications.

With a decade of new data to review, we now reappraise the relationship between intravascular hemolysis and the pathophysiology of SCD and further extend the role of intravascular hemolysis and NO scavenging to other diseases.

\section{Evidence that hemolysis modulates SCD subphenotypes}

SCD phenotypes are expressed in common and rare subphenotypes. Some subphenotypes are attributed to sickle vaso-occlusive events triggered by adherent sickle erythrocytes and are closely related to packed cell volume, blood viscosity, and inflammation/ intracellular adhesion. Other events are a presumed consequence of intravascular hemolysis of injured sickle cells. Table 1 lists common subphenotypes of disease and their epidemiological associations with biomarkers of hemolytic anemia and inflammation/viscosity/vaso-occlusion. $\mathrm{HbF}$ and $\alpha$-thalassemia are the two principal modulators of the SCD phenotype. HbF has its most robust effects on subphenotypes associated with sickle vaso-occlusion, including ACS (30-32). Failure of $\mathrm{HbF}$ to afford similar levels of protection for hemolysis-associated subphenotypes might be a consequence of insufficient $\mathrm{HbF}$ in some cells, which allows continued intravascular hemolysis and endothelial injury over long exposures $(33,34)$.

$\alpha$-Thalassemia modulates the phenotype of SCD by reducing hemolysis (35). $\alpha$-Thalassemia reduces mean cell hemoglobin 
concentration and erythrocyte density, thereby reducing the tendency of deoxy-HbS to polymerize (35). In compound heterozygotes for $\alpha$-thalassemia and sickle cell anemia (SCA, characterized by homozygosity for the $\mathrm{HbS}$ gene), hemoglobin levels are higher and the prevalence of subphenotypes associated with hemolytic anemia are reduced in comparison with SCA alone; in contrast to SCA, the prevalence of vaso-occlusive pain crisis and the prevalence of ACS are increased (36). Consistent with this observation, in a placebo-controlled clinical trial in adults with SCA, a Gardos channel inhibitor significantly reduced hemolysis, increased hemoglobin levels, and increased the rate of vaso-occlusive painful episodes (37). Reduction of hemolysis by the Gardos channel inhibitor was associated with significant decline in serum N-terminal pro-B-type natriuretic peptide (NT-proBNP) (38), potentially consistent with decreased pulmonary artery pressure, but also possibly caused simply by improved anemia and lower cardiac preload (39). The results of this antihemolytic pharmacological intervention substantially phenocopy SCA- $\alpha$-thalassemia, further supporting phenotypic modulation of SCD by hemolysis and anemia. Other than increased blood viscosity, only increased adhesiveness is hypothesized to mediate the increased risk of vasoocclusion in SCA- $\alpha$-thalassemia (40), but no published evidence supports this alternative hypothesis.

Many studies have confirmed the association of indirect markers of hemolysis with certain complications of disease. Hemolytic rate in SCD has been measured directly by labeled-erythrocyte survival studies $(34,41)$. More often, indirect surrogates of red cell lifespan, including plasma hemoglobin, total hemoglobin, erythrocyte microparticles, serum bilirubin, reticulocyte count, lactate dehydrogenase (LDH), alanine aminotransferase (AST), and urine hemosiderin or cell-free hemoglobin, have been used singly and in combination to estimate the hemolysis intensity $(20,25)$. Composite indices characterizing hemolysis severity were validated by comparison with the plasma levels of cell-free hemoglobin and red blood cell microparticles. These measures correlate appropriately with hemoglobin and reticulocyte counts and are decreased in patients with high $\mathrm{HbF}$ or with $\alpha$-thalassemia (25). Based on plasma hemoglobin measurements, the fraction of intravascular hemolysis ranges from less than $10 \%$ to more than $30 \%$, while total plasma hemoglobin concentrations (reported here in terms of heme concentration) range from 0.25 to more than $20 \mu \mathrm{M}(16)$. As discussed later, these concentrations are sufficient to scavenge NO and perhaps trigger sickle vasculopathy.

\section{Hyperhemolysis-associated SCD subphenotypes}

A suggested paradigm proposes a gradient of hemolysis among SCD patients, with the highest quartile of this gradient sometimes referred to as hyperhemolysis (19-23, 25, 26, 41, 42-47). This gradient results from the differential distribution of $\mathrm{HbF}$ concentrations among sickle erythrocytes, the presence or absence of $\alpha$-thalassemia mutations, and perhaps other genetic determinants that directly or indirectly affect erythrocyte lifespan (36). Included in the vasculopathic subphenotypes associated with hyperhemolysis are $\mathrm{PH}$, cerebrovascular disease, leg ulcers, priapism, and sickle nephropathy (20). Tricuspid regurgitant velocity (TRV) and serum NT-proBNP are markers of pulmonary vascular disease and myocardial wall stress and are consistently associated with hyperhemolysis $\left(19,39,44,48^{-56}\right)$. PH, either screened for with TRV or definitively ascertained by right heart catheterization, is closely associated with the intensity of hemolysis and mortality (discussed below). Some aspects of the hemolytic phenotype, like abnormally high TRV and PH confirmed by right heart catheterization, are seen in other hemolytic anemias where intravascular hemolysis is common (and vaso-occlusive crisis is absent) like $\beta$-thalassemia (57). Similarly to SCD (58), these other hemolytic disorders also feature a hypercoagulable state with evidence of microthrombotic disease in the pulmonary vasculature (59).

\section{Hemolytic anemia and vasculopathic complications}

Numerous cohort studies evaluated and confirmed the association of hemolytic anemia severity with increasing pulmonary pressures estimated by TRV and directly measured by right heart catheterization. Many of these studies also evaluated the relationship between estimated or directly measured pulmonary artery pressures and reduced exercise capacity and/or risk of death. These studies include the NIH-PH (19), Duke (60), UNC (49), MSH (39), CSSCD (54), PUSH (50, 61), and Walk-PHASST (51) cohorts, a Greek cohort (62), and a recent 656-SCD-patient echocardiographic screening study in Créteil, France (63). The analysis of more than 600 screening patients in both the Walk-PHASST and Créteil cohorts found similar associations between indices of hemolytic anemia, high TRV, and risk of death $(51,63)$. These associations were largely confirmed in right heart catheterization studies (64-66).

Severity of hemolytic anemia was associated not only with risk of precapillary $\mathrm{PH}$, but also with risk of postcapillary $\mathrm{PH}$. The latter was observed with echocardiographic markers of heart failure with preserved ejection fraction (67-70) and right heart catheterization (64-66). The involvement of left ventricular disease complicates the diagnosis, clinical management, and prognosis in SCD, as discussed below.

While hemolytic anemia is an independent risk factor for vasculopathic complications, hemolysis does not occur in isolation. Priapism and leg ulcers occur more frequently in SCD patients than in patients with other hemolytic diseases like paroxysmal nocturnal hemoglobinuria $(\mathrm{PNH})$, spherocytosis, $\beta$-thalassemia, and pyruvate kinase deficiency, which surely represents the contribution of unique characteristics of the sickle erythrocyte, sickle vaso-occlusion, and inflammatory damage to intravascular hemolysis-provoked injury. This is particularly evident in the epidemiology of priapism, in which indices of both hemolytic anemia and inflammation are associated with this clinical manifestation (71). A nexus between hemolysis and sickle vaso-occlusion might lay in the increased adhesivity of the sickle reticulocyte, sickle erythrocyte lysis in vaso-occluded regions (discussed below), and downstream inflammatory effects of intravascular hemolysis products, like heme, that drive sterile inflammation.

\section{Elevated TRV and SCD complications}

TRV can be quantified by Doppler echocardiography and used to estimate pulmonary artery systolic pressure. This value is a predictive physiological biomarker and a widely used screening test for $\mathrm{PH}$. While TRV has important limitations in sensitivity and specificity, it is a continuous variable that is inversely proportional to exer- 


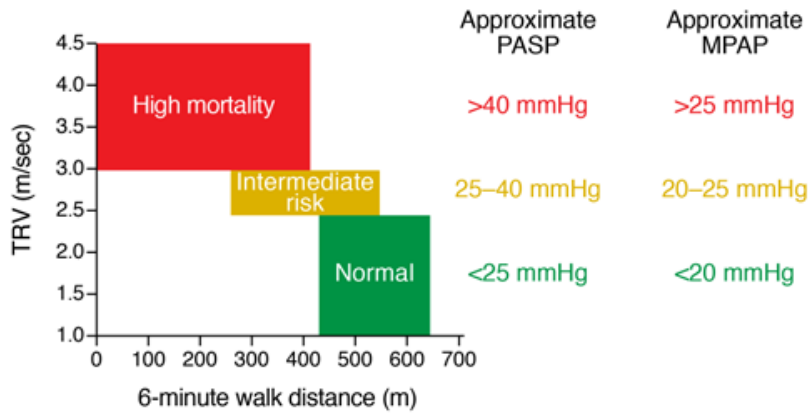

Figure 1. Tricuspid regurgitant velocity on echocardiogram is a physiological biomarker that predicts survival and functional outcomes. Tricuspid regurgitant velocity (TRV) that is less than two SD below the population mean is in the normal range $(<2.5 \mathrm{~m} / \mathrm{s})$, is associated with normal calculated pulmonary artery systolic pressures (PASP, $<25 \mathrm{mmHg}$ ), and generally corresponds to a mean pulmonary artery pressure (MPAP, $<20 \mathrm{mmHg}$ ), good longterm survival, and good exercise tolerance, as indicated by a higher 6-minute walk distance $(>400 \mathrm{~m})$. Conversely, highly elevated TRV that is more than 3 $\mathrm{SD}$ above the mean $(\geq 3 \mathrm{~m} / \mathrm{s}$ ) is strongly associated with poor exercise tolerance with lower 6 -minute walk distance $(<400 \mathrm{~m})$, pulmonary artery systolic pressure greater than $40 \mathrm{mmHg}$, mean pulmonary artery pressure greater than $25 \mathrm{mmHg}$ on right heart catheterization, and significantly poorer long-term survival. Intermediate TRV level $(2.5-2.9 \mathrm{~m} / \mathrm{s})$ is associated with intermediate risk of exercise intolerance and mortality. Figure is adapted with permission from the Journal of the American Medical Association (39) and the American Journal of Respiratory and Critical Care Medicine (74).

cise capacity measured by the 6-minute walk distance and directly related to rising risk of death in adults with $\operatorname{SCD}(19,49,51,60,63$, 72). However, clinical decision making demands widely used categorical classifications. TRV $=2.5 \mathrm{~m} / \mathrm{s}$ represents $2 \mathrm{SD}$ above the population mean; TRV $\geq 3 \mathrm{~m} / \mathrm{s}$ is $3 \mathrm{SD}$ above the mean. SCD patients with $T R V \geq 2.5 \mathrm{~m} / \mathrm{s}$ have a lower exercise capacity and survival time (Figure 1). For example, in the Créteil study, probability of death was low in SCD patients with a TRV $\leq 2.5 \mathrm{~m} / \mathrm{s}$, while a TRV $\geq 2.5 \mathrm{~m} / \mathrm{s}$ was associated with a hazard ratio of 6.81 in multivariate analysis and rose linearly above this value with a $50 \%$ probability of death at TRV $=3.2 \mathrm{~m} / \mathrm{s}$ (63). These findings are consistent with other large cohort studies $(19,51,63,72)$, as results from both the NIH-PH cohort and the Paris cohort suggest that approximately $64 \%-75 \%$ of SCD patients with $\mathrm{TRV} \geq 3 \mathrm{~m} / \mathrm{s}$ have $\mathrm{PH}$ defined by pulmonary artery catheterization documentation of mean pulmonary artery pressure greater than $25 \mathrm{mmHg}$, approximately $3 \mathrm{SD}$ above the normal mean value $(64,65)$. SCD patients who fall into the intermediate category of TRV $=2.5-2.9 \mathrm{~m} / \mathrm{s}$ (between 2 and $3 \mathrm{SD}$ from the mean) have intermediate exercise capacity and mortality, falling squarely between the $T R V \leq 2.5 \mathrm{~m} / \mathrm{s}$ group and the TRV $\geq 3 \mathrm{~m} / \mathrm{s}$ group. Catheterization studies indicated that about $25 \%$ of these patients have a mean pulmonary artery pressure greater than $25 \mathrm{mmHg}$, supporting the low but significant predictive value of an intermediate TRV for identifying patients at risk of $\mathrm{PH}$ (65). Thus, the TRV category is predictive of the risk of both $\mathrm{PH}$ and mortality. TRV $\geq 2.5 \mathrm{~m} / \mathrm{s}$ also predicts a higher risk of leg ulcers $(46,60)$, thrombosis $(58)$, proteinuria $(60,73)$, and exercise intolerance $(74,75)$, suggesting that it also serves as a marker for more general vasculopathy.

Meta-analysis helped sort out the many different studies of the prevalence and risk of high TRV in SCD. This meta-analysis included 45 studies from 15 countries and 6,109 patients (47).
Prevalence of elevated TRV $\geq 2.5 \mathrm{~m} / \mathrm{s}$ was $21 \%$ in children and $30 \%$ in adults. In random-effects meta-analyses, the 6-minute walk was $30.4 \mathrm{~m}$ less in patients with elevated TRV than in those without elevated TRV, and the associated mortality hazard ratio was 4.9. Mortality among high-TRV SCD patients seems to be limited to adults, suggesting the testable hypothesis that high TRV in childhood predicts future risk of mortality later in adulthood. Mortality estimates are likely becoming more accurate as the number of screened adults and duration of follow-up increase.

\section{$\mathrm{PH}$ and mortality in SCD}

In general, right heart catheterization is required for a definitive diagnosis of $\mathrm{PH}$, which is defined by a mean pulmonary artery pressure of at least $25 \mathrm{mmHg}$, although it is increasingly appreciated that mean pressures between 20 and $25 \mathrm{mmHg}$ are not normal and might predict reduced exercise capacity and risk. Three SCD hemodynamic studies, from the US, Brazil, and France, evaluated the prevalence of $\mathrm{PH}$ defined by right heart catheterization in SCD and examined associated clinical risk factors and prospective risk of death. In the study with the longest follow-up times, performed at the NIH, 531 SCD patients were evaluated with a median follow-up time of 4.7 years and a maximum of 11 years for surviving subjects $(64,76)$. In this cohort, 84 right heart catheterizations were performed. Fifty-five of 531 SCD subjects (10.4\%), or 55 of 84 (65.5\%) of those who underwent catheterization, had PH; slightly more than half had pulmonary arterial hypertension (precapillary), and the other half had pulmonary venous hypertension. PH was associated with higher LDH levels and lower hemoglobin levels, higher prevalence of leg ulcers and renal insufficiency, and lower exercise capacity, defined by worse functional classification and lower 6-minute walk distance $(64,76)$.

Survival estimates for SCD patients with $\mathrm{PH}$ was $63 \%$ at 5 years, compared with $83 \%$ for SCD patients with normal right heart catheterization. Death certificates were available for $65 \%$ of SCD patients who died, and $80 \%$ of these reported right heart failure or sudden cardiac death, a cause of death seen commonly in the general pulmonary arterial hypertension population (77). Multivariate analysis of hemodynamic variables identified pulmonary vascular resistance, transpulmonary gradient, and pulmonary artery systolic and diastolic pressures as predictors of mortality. SCD patients with $\mathrm{PH}$ who died had worse hemodynamic values than survivors: mean pulmonary artery pressures of $39 \pm 9$ versus $33 \pm 7 \mathrm{mmHg}(P<0.001)$, transpulmonary gradient of $25 \pm$ 10 versus $17 \pm 8 \mathrm{mmHg}(P=0.003)$, and pulmonary vascular resistance of $279 \pm 164$ versus $189 \pm 127 \mathrm{dyn} \cdot \mathrm{s} / \mathrm{cm}^{5}(P=0.017)$ strongly suggested that mortality rate in adults with SCD is proportional to severity of precapillary pulmonary vascular disease $(64,76)$.

In the Brazilian study, 80 SCD patients were screened, and 26 with elevated estimated pulmonary artery systolic pressures by Doppler echocardiography had right heart catheterizations (66). Ten percent of patients had $\mathrm{PH}$, with worse survival compared with the remaining patients. Patients with $\mathrm{PH}$ had lower hemoglobin and higher LDH levels, proteinuria, renal insufficiency, and lower 6-minute walk distance. The third study, in France, was also consistent with primary observations from the previously discussed trials (65). After exclusion of adults with greater disease severity, $6 \%$ of all screened adults had $\mathrm{PH}$ (46\% precapillary and 
Table 2. A comparison of SCD cohorts studied with right heart catheterization

$\begin{array}{lccc}\text { Population characteristics } & \text { NIH-PH (64) } & \text { Paris (65) } & \text { São Paulo (66) } \\ \text { Exclusions } & \text { None } & \text { Lung, liver, renal disease } & \text { None } \\ \text { Prevalence of TRV } \geq 2.5 \mathrm{~m} / \mathrm{s} & 32 \% & 27 \% & 40 \% \\ \text { Prevalence of MPAP } \geq 25 \mathrm{mmHg} & 11 \% & 6 \% & 10 \% \\ \text { Findings in SCD PH vs. others } & & & \\ \text { Age } & \text { Older } & \text { Older } & \text { Older } \\ \text { History of leg ulcers } & \text { Yes } & \text { Yes } & \text { Yes (significant only with TRV) } \\ \text { History of frequent VOC or ACS } & \text { No } & \text { No } & \text { No } \\ \text { NT-proBNP } & \text { High } & \text { High } & - \\ \text { Hemoglobin } & \text { Low } & \text { Low } & \text { Low } \\ \text { LDH } & \text { High } & \text { High } & \text { High } \\ \text { AST } & \text { High } & \text { High } & \text { High } \\ \text { Alkaline phosphatase } & \text { High } & \text { High } & - \\ \text { Direct bilirubin } & \text { High } & \text { High } & \text { High } \\ \text { Creatinine } & \text { High } & \text { High } & \text { Low } \\ \text { 6MWD } & \text { Low } & \text { Low } & - \\ \text { NYHA functional class } & \text { High } & \text { High } & \text { High } \\ \text { Mortality } & \text { High } & \text { High } & \text { L }\end{array}$

VOC, vaso-occlusive crisis; 6MWD, 6-minute walk distance; NYHA, New York Heart Association. with TRV elevations and impairments in flow-mediated vasodilation, a measure of endothelial NOS-dependent vasodilation (80). In the Berkeley sickle mouse, high plasma hemoglobin levels correlated with impaired blood flow responses to infusions of the NO donor sodium nitroprusside (81). In a recent study, a specific hemoglobin-scavenging peptide that depleted the levels of plasma hemoglobin restored endothelial NOS-dependent vasodilation (82).

$P H$ in other animal models of hemolysis. Multiple mouse models of hemolysis exhibited increased plasma hemoglobin and increased plasma NO scavenging and developed spontaneous $\mathrm{PH}$ and right heart failure, including Berkeley sickle cell (78), spherocytosis (83), $\alpha$-thalassemia (84), PNH (85), and alloimmune hemolysis mice (78).

NO resistance. $\mathrm{NO}$ resistance is characterized by impaired vasodilatory respons-

$54 \%$ postcapillary). Exclusion of subjects likely underestimated the true prevalence of $\mathrm{PH}$, because markers of renal insufficiency, hepatic dysfunction, and iron overload are independent risk factors for high estimated pulmonary artery pressure in SCD. Patients with right heart catheterization-documented $\mathrm{PH}$ had lower hemoglobin and higher LDH values and higher prevalence of prior leg ulcers, and all deaths occurred in this subgroup (65).

All of these right heart catheterization screening studies likely underestimate $\mathrm{PH}$ prevalence, as not all patients with elevated TRV agreed to catheterization. The differences and similarities between these three studies are summarized in Table 2 .

\section{Evidence linking cell-free hemoglobin to SCD complications}

Epidemiological studies of the associations between $\mathrm{PH}$ and other vasculopathic subphenotypes of SCD have been supported by mechanistically focused studies. The primary hypothesis that intravascular hemolysis releases cell-free plasma hemoglobin and arginase 1 to inactivate the NO signaling axis and redox balance was studied over the last 10 years in animal models and in vivo in humans. In addition to studies in humanized transgenic sickle cell mice, studies have now been performed in other diseases with significant intravascular hemolysis, including murine models of $\mathrm{PNH}$, thalassemia, and malaria, and aged-blood transfusion models. Many of the studies test causality, with the addition of hemoglobin and hemoglobin inhibition by oxidation and haptoglobin therapy. We briefly review the preclinical and clinical experimental evidence below.

Vasomotor defect in SCD. SCD patients and sickle transgenic mice have impaired vasodilator responses to NO that are proportional to levels of plasma hemoglobin $(16,78-80)$. In humans, impaired NO signaling, directly measured via venous occlusion strain-gauge plethysmography, correlates with high levels of plasma hemoglobin and LDH (16). This was recently confirmed in a study of SCD patients correlating high plasma hemoglobin levels es to infusions of NO donors, pulmonary and systemic vasoconstriction, and $\mathrm{PH}$. In animals, inducing intravascular hemolysis or infusing hemoglobin or hemolysate can produce experimental NO resistance (86-89). This effect is attributable to hemoglobin and NO scavenging, as it can be blocked by oxidization of hemoglobin to methemoglobin with inhaled NO gas or by binding and clearance of hemoglobin with haptoglobin $(86,89-91)$. Acute intravascular hemolysis induced by hypotonic water infusion in mice inhibits NO signaling and causes inflammation, an effect phenocopied by acute NO inhibition using chemical NO scavengers and reversed by an NO donor and haptoglobin (92). Haptoglobin prevents extravasation of free hemoglobin into interstitial spaces, where it scavenges NO (91).

Stored blood and vasomotor defect. Infusing aged stored blood into rodents $(89,93,94)$ and humans $(90,95)$ causes intravascular hemolysis, pulmonary and systemic hypertension, and vascular endothelial dysfunction (due to impaired NO signaling) that can be blocked by haptoglobin (96). These effects are not always observed in models or patient populations in which hemolysis is not as severe, the dose of transfused red cells is not large, and the existing compensatory reserves of haptoglobin, hemopexin, and catalytic antioxidants are not as chronically depleted as in SCD.

Malaria endothelial dysfunction. Animal and human malaria is associated with intravascular hemolysis, increases in plasma hemoglobin, and impaired NO signaling. Higher level of plasma hemoglobin correlates in patients with impaired endothelial function $(97,98)$ and increased estimated pulmonary artery pressures (99). In animal models, it is linked to lowered NO scavenging and increased risk of death (21). Inhaled NO is protective in rodent models of malaria $(21,100,101)$.

\section{Hemolysis, plasma heme, and erythrocyte danger-associated molecular patterns}

Free heme, another product of intravascular hemolysis, is released from free hemoglobin upon oxidation. Free heme is increasingly 


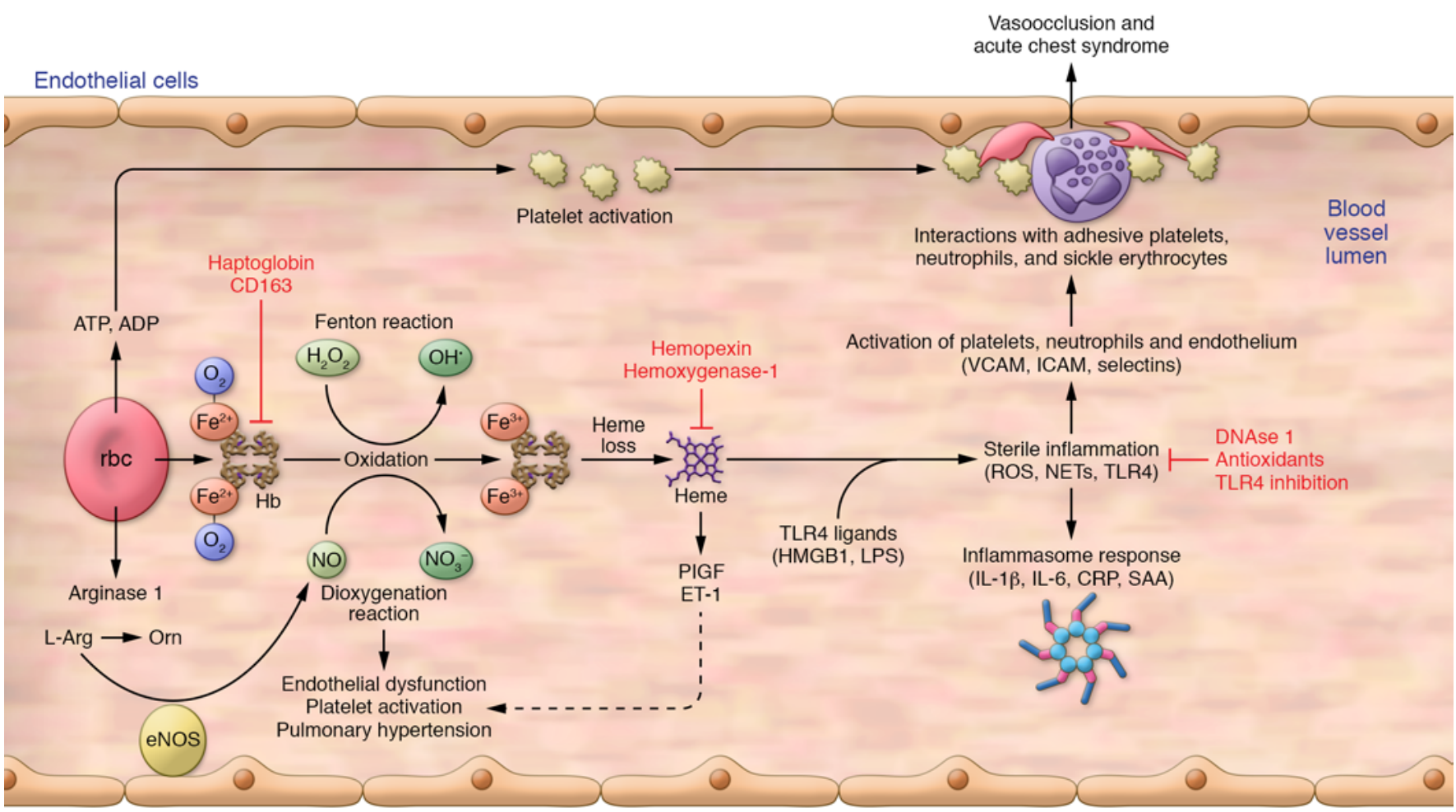

Figure 2. Contribution of intravascular hemolysis to vasculopathy and vasoocclusion. Intravascular hemolysis produces free hemoglobin, which drives Fenton reactions to produce oxidants and scavenges NO by a dioxygenation reaction. Intravascular hemolysis also releases red cell arginase 1 into plasma, where it can deplete plasma L-arginine (L-Arg), the required substrate for NO production by eNOS. Oxidized hemoglobin releases free heme, which can activate release of placenta growth factor (PICF) and endothelin-1 (ET-1). These combined pathways contribute to chronic vasculopathy, platelet activation, and pulmonary hypertension. Heme also primes the innate immune system to acute rises in endogenous (HMGB1) and exogenous (LPS) ligands of TLR4. These in turn activate production of ROS, neutrophil extracellular traps (NETs), and downstream activation of the inflammasome, producing inflammatory cytokines and other mediators that promote expression of adhesion receptors and ligands on endothelium and blood cells. Intravascular hemolysis also releases adenine nucleotides, including ATP and ADP, which further contributes to platelet activation. There is also some evidence that adenosine binds receptors on red cells, resulting in increased 2,3-diphosphoglycerate and sphingosine-1-phosphate, associated with lower oxygen affinity of hemoglobin (not shown). Proteins on the surface of the activated endothelium (P-selectin, E-selectin, VCAM1, ICAM1) interact with adhesive platelets, neutrophils, and sickle erythrocytes, producing vasoocclusion and acute chest syndrome. Intravascular hemolysis also releases asymmetric dimethylarginine, which inhibits eNOS. CRP, C-reactive protein; SAA, serum amyloid A; Orn, ornithine. Adapted with permission from Gladwin, et al., Journal of Clinical Investigation (150).

appreciated as an additional important mediator of inflammation and vascular injury $(102,103)$. In sickle cell mice, free heme drives inflammation, vaso-occlusion, and coagulation that are blocked by the heme scavenger hemopexin (104-109). In cultured cells, heme promotes secretion of high levels of placenta growth factor (110), which in turn induces release of the potent vasoconstrictor endothelin 1 (111), a common mediator of PH. Heme is a potent source of oxidant stress, but it does not scavenge NO.

Hemoglobin oxidation is driven not only by reaction with NO (112), but also by reaction with a host of additional physiological oxidants (113-118). Ferric and ferryl forms of hemoglobin produced in SCD and other forms of hemolysis are highly reactive in promoting oxidation (119-121). Hemolysis also produces red cell microparticles that can deliver toxic heme to endothelial cells $(122,123)$. Heme species appear to activate innate immune sterile inflammation pathways through TLR4 and NALP inflammasome signaling $(104,105,124,125)$. As such, these hemolysis products are proposed to represent erythrocyte danger-associated molecular patterns (eDAMPs), which promote and propagate sterile inflammatory and oxidative stress, further impairing the redox balance $(126,127)$. eDAMP release and oxidation of plasma hemoglobin to methemoglobin, which is necessary for the release of heme, are likely enhanced during acute vaso-occlusive episodes. To date, a careful stoichiometric analysis of cell-free hemoglobin levels, heme levels, and heme in microparticles during sickle vaso-occlusion has not been performed. Heme, hemoglobin, and red cell ADP activate platelets and stimulate platelet mitochondria to produce ROS and cause an oxidative enzymopathy of complex V (the ATPase), resulting in platelet activation, thrombospondin- 1 and PDGF release, and promotion of inflammation and vasculopathy (128). eDAMPs trigger innate immune responses, perhaps in the setting of LPS-priming of the NALP3 inflammasome, and might be central to the sterile inflammation that is characteristic of sickle vaso-occlusion.

In this context, we propose that steady-state intravascular hemolysis primarily inhibits NO signaling and amplifies ROS formation, tipping the redox balance and producing endothelial dysfunction (Figure 2). With advancing age, this effect drives development of vasculopathic complications that characterize the subphenotypes of SCD most closely associated with hemolysis. Steady-state inflammation and increased blood viscosity also promote cellular adhesion and vaso-occlusion, leading to acute painful episodes and organ ischemia/reperfusion injury. These mecha- 
nisms intersect, perhaps during severe vaso-occlusive painful crisis when acute hemolysis is triggered and oxidant stress enhances hemoglobin oxidation and heme release. This intersection activates primed innate immune signaling pathways and the inflammasome, leading to multisystem injury and acute lung injury.

\section{Controversies regarding the hyperhemolysis model}

The role of hyperhemolysis as a proximate cause of some SCD complications has drawn criticism. In some cases, this was a dispute over nomenclature; in others, similar data were interpreted differently $(11,12)$. Importantly, the debate has not centered on reproducibility, as strong associations between morbidity and mortality and measures of cell-free plasma hemoglobin and other markers of hemolysis, TRV, and PH remain robust. Similarly, strong consensus surrounds the vasoactivity and injurious effects of hemolysate, cell-free hemoglobin, and heme. Some of these controversies actually represent consensus, and are summarized in the following objections and responses:

Echocardiography-defined TRV is not adequate to diagnose $\mathrm{PH}$. This is clearly true. TRV is a physiological biomarker representing PH risk, much as transcranial Doppler velocity represents stroke risk in children with SCA. PH diagnosis requires pulmonary artery catheterization. TRV $\geq 3 \mathrm{~m} / \mathrm{s}$ appears to have about $75 \%$ specificity for $\mathrm{PH}$ in adults with $\operatorname{SCD}(64,65)$. TRV $\geq 2.5 \mathrm{~m} / \mathrm{s}$ specificity is approximately $25 \%$ for $\mathrm{PH}$, but the addition of abnormally short 6-minute walk distance (64) or elevated serum NT-proBNP (65) can enhance identification of high-risk patients in this intermediate TRV group. Elevated TRV unequivocally represents a higher risk of $\mathrm{PH}$ diagnosed by right heart catheterization $(19,64)$, but this can be confounded by high cardiac output, error in the estimation of TRV, and other sources of variability. TRV also represents an elevated risk of impaired exercise tolerance, proteinuria, venous thromboembolism, and mortality (Figure 1 and refs. 58, 129, 130).

$\mathrm{PH}$ does not occur in $34 \%$ of SCD adults. This is correct. Approximately $6 \%-10 \%$ of SCD adults have $\mathrm{PH}$ defined by a mean pulmonary artery pressure greater than or equal to $25 \mathrm{mmHg}$, measured by pulmonary artery catheterization (64-66). However, another $25 \%$ of patients have mildly elevated TRV, which is prognostically significant, as discussed above, and mean pressures between 20 and $25 \mathrm{mmHg}$ are abnormally high and likely consequential.

$P H$ in SCD is caused by left ventricular diastolic dysfunction. Several echocardiography and right heart catheterization studies have shown that half of PH cases in SCD involve precapillary PH consistent with inappropriately high pulmonary vascular resistance, leading to right ventricular hypertrophy and failure $(64-66,74,131)$. The other half comprise postcapillary $\mathrm{PH}$, associated with a stiff left ventricle due to ventricular hypertrophy and linked to anemia and chronically high cardiac output $(64-66,68,74)$. Even in patients with high left atrial pressures, the risk of death most closely associates with increases in the intrinsic pulmonary vascular resistance (high pulmonary vascular resistance and transpulmonary pressure gradient). An additional mechanism of cardiomyocyte dropout and cardiomyopathy has been found in sickle mice (132).

Serum LDH is not a good biomarker of hemolysis. In large population studies, LDH values in homozygous SS patients are correlated with higher levels of more direct markers of intravascular hemolysis, cell-free plasma hemoglobin, and red cell-derived microparti- cles (89). LDH values also correlate in human physiological studies with an impaired response to NO donor infusions. However, LDH has limitations as a marker of hemolysis, since it is released by lytic damage of almost any tissue, which occurs in patients with SCD. Its assay methodology varies among different clinical laboratories, complicating multicenter analyses. Serum LDH is a biomarker of intravascular hemolysis, which releases free hemoglobin and arginase. Both are integral to the hyperhemolysis model of NO scavenging (10). Phagocytosis of damaged red cells by macrophages or extravascular hemolysis is not expected to release free hemoglobin or LDH into plasma. Red cell survival studies do not distinguish between extravascular and intravascular hemolysis (133). Significant variability in serum LDH in steady-state SCD adults is provided by LDH isoforms originating from red cells but also found in renal cells (20). Until better biomarkers for intravascular hemolysis are available, only serum $\mathrm{LDH}$, aspartate aminotransferase, and plasma hemoglobin can be used to imperfectly indicate intensity of intravascular hemolysis.

Decreased NO bioavailability cannot be the sole mechanism of vasculopathy in SCD. This is also correct. Published data evidence the involvement of oxidative stress $(79,100,105,108,113,115,116$, $121,123,132,134,135)$, inflammation $(9,22,27,32,101,105-108$, $115,124-127,134)$, dyslipidemia (135-138), microparticles $(89,122$, $123,139)$, and vasoactive peptides $(110,111,140-143)$. These additional pathways (depicted in Figure 2) are potentially additive or synergistic to intravascular hemolysis-like mechanisms. We note that hemolysis potently impairs redox balance, lowering NO signaling and enhancing pathological ROS signaling.

Markers of hemolysis do not correlate with red cell survival. A recent study limited to 13 measurements failed to find such correlations (133). This small study considered only 11 pediatric SCA patients with very low levels of basal hemolysis based on hydroxyurea treatment, many with $\alpha$-thalassemia trait, and most having unusually high levels of $\mathrm{HbF}$ (10 of 13 measurements came from patients with $\mathrm{HbF}$ levels greater than $9 \%$, including one of $33.8 \%$ ). Measuring correlations of hemolysis markers in patients with limited hemolysis does not adequately test biomarkers. These studies should be performed in adult patients with clinically relevant ranges of hemolytic severity. Additionally, red cell survival (total hemolysis) in SCD is believed to be dominated by extravascular hemolysis (144), which is not the mechanism proposed to scavenge NO. Presently, plasma hemoglobin, serum LDH, and AST, with all their limitations, remain the best available biomarkers of intravascular hemolysis. Intravascular hemolysis must not be confused with extravascular hemolysis.

\section{Conclusions}

Epidemiological associations and mechanistic causal testing support the pathogenic role of intravascular hemolysis in SCD. New understanding of the role of red cell hemolysis products, redox disequilibrium, and eDAMPs in the end-organ injury observed in SCD provides a pathway for identifying counterregulatory signaling pathways that might dampen sterile inflammation and oxidative stress, e.g., upregulation and protective polymorphisms in the heme oxygenase-1 enzyme $(134,145)$. Upstream activation of the KEAP1/NRF2 redox sensing transcription pathway, a central counterregulatory program that protects against oxidative and hemolytic stress, is being actively investigated as a therapy for SCD (146, 
147). As clinical trials are planned, it will be vital to target drugs to specific subphenotypes of SCD when considering treatments beyond the direct inhibition of deoxy-HbS polymerization. Given the results of the Gardos channel inhibitor clinical trial, new drugs that reduce hemolysis and increase hemoglobin levels should be used cautiously, possibly in combination with optimal dosing of hydroxyurea or other agents that directly inhibit $\mathrm{HbS}$ polymerization by inducing high levels of $\mathrm{HbF}$, or another mechanism to limit viscosity, inflammation, and vaso-occlusion and its complications. Drugs that promote cGMP signaling, such as soluble guanylate cyclase stimulators, should be tested with caution, as the phosphodiesterase 5 inhibitor sildenafil induced painful crisis in clinical trials (148). Development of promising hemoglobin- and heme-scavenging agents is likely limited to more acute therapy in the setting of hyperhemolysis, akin to the use of eculizumab for hemolytic uremic syndrome. Common nodes that intersect both hemolysisendothelial dysfunction and viscosity/vaso-occlusion, such as the KEAP1/NRF2 pathway and NALP3 inflammasome, might be ideal targets for therapy. Hydroxyurea is a prototype for such an agent, as it inhibits $\mathrm{HbS}$ polymerization via $\mathrm{HbF}$ induction and is metab- olized in vivo to form NO $(92,149)$. Finally, intravascular hemolysis is surely not the only source of vasculopathy in SCD, and more vigorous research is needed on the role of oxidases, oxidant stress, eDAMPs, and the inflammasome pathway.

\section{Acknowledgments}

M.T. Gladwin receives research support from NIH grants 2R01HL098032, 1R01HL125886-01, 2P01HL103455, and T32HL110849. G.J. Kato is supported by NIH grants 1R01HL121386 and 1R01MD009162 and the Patient-Centered Outcomes Research Institute. M.T. Gladwin and G.J. Kato both are supported by the Institute for Transfusion Medicine and the Hemophilia Center of Western Pennsylvania. M.H. Steinberg is supported by NIH grants R01HL068970, RC2HL101212, R01HL87681, 5T32HL007501, and 5U01HL107443.

Address correspondence to: Mark T. Gladwin, Department of Medicine, University of Pittsburgh School of Medicine, 1218 Scaife Hall, 3550 Terrace Street, Pittsburgh, Pennsylvania 15261, USA. Phone: 412.648.3181; E-mail: gladwinmt@upmc.edu.
1. van Beers EJ, et al. Imaging flow cytometry for automated detection of hypoxia-induced erythrocyte shape change in sickle cell disease. Am J Hematol. 2014;89(6):598-603.

2. Serjeant GR, Serjeant BE, Mason K. Heterocellular hereditary persistence of fetal haemoglobin and homozygous sickle-cell disease. Lancet. 1977;1(8015):795-796.

3. Noguchi CT, Torchia DA, Schechter AN. Intracellular polymerization of sickle hemoglobin. Effects of cell heterogeneity. JClin Invest. 1983;72(3):846-852.

4. Fabry ME, Nagel RL. Heterogeneity of red cells in the sickler: a characteristic with practical clinical and pathophysiological implications. Blood Cells. 1982;8(1):9-15.

5. Platt OS, et al. Pain in sickle cell disease. Rates and risk factors. N Engl J Med. 1991;325(1):11-16.

6. Barabino GA, Platt MO, Kaul DK. Sickle cell biomechanics. Annu Rev Biomed Eng. 2010;12:345-367.

7. Telen MJ. Cellular adhesion and the endothelium: E-selectin, L-selectin, and pan-selectin inhibitors. Hematol Oncol Clin North Am. 2014;28(2):341-354.

8. Kutlar A, Embury SH. Cellular adhesion and the endothelium: P-selectin. Hematol Oncol Clin North Am. 2014;28(2):323-339.

9. Zhang D, Xu C, Manwani D, Frenette PS. Neutrophils, platelets, and inflammatory pathways at the nexus of sickle cell disease pathophysiology. Blood. 2016;127(7):801-809.

10. Kato GJ, Gladwin MT, Steinberg MH. Deconstructing sickle cell disease: reappraisal of the role of hemolysis in the development of clinical subphenotypes. Blood Rev. 2007;21(1):37-47.

11. Hebbel RP. Reconstructing sickle cell disease: a data-based analysis of the "hyperhemolysis paradigm" for pulmonary hypertension from the perspective of evidence-based medicine. $A m \mathrm{~J}$ Hematol. 2011;86(2):123-154.

12. Bunn HF, et al. Pulmonary hypertension and nitric oxide depletion in sickle cell disease. Blood. 2010;116(5):687-692.
13. Rother RP, Bell L, Hillmen P, Gladwin MT. The clinical sequelae of intravascular hemolysis and extracellular plasma hemoglobin: a novel mechanism of human disease. JAMA. 2005;293(13):1653-1662.

14. Doyle MP, Hoekstra JW. Oxidation of nitrogen oxides by bound dioxygen in hemoproteins. J Inorg Biochem. 1981;14(4):351-358.

15. Alayash AI, Cashon RE. Hemoglobin and free radicals: implications for the development of a safe blood substitute. Mol Med Today. 1995;1(3):122-127.

16. Reiter CD, et al. Cell-free hemoglobin limits nitric oxide bioavailability in sickle-cell disease. Nat Med. 2002;8(12):1383-1389.

17. Morris CR, et al. Dysregulated arginine metabolism, hemolysis-associated pulmonary hypertension, and mortality in sickle cell disease. JAMA. 2005;294(1):81-90.

18. Landburg PP, et al. Plasma asymmetric dimethylarginine concentrations in sickle cell disease are related to the hemolytic phenotype. Blood Cells Mol Dis. 2010;44(4):229-232.

19. Gladwin MT, et al. Pulmonary hypertension as a risk factor for death in patients with sickle cell disease. NEngl J Med. 2004;350(9):886-895.

20. Kato GJ, et al. Lactate dehydrogenase as a biomarker of hemolysis-associated nitric oxide resistance, priapism, leg ulceration, pulmonary hypertension, and death in patients with sickle cell disease. Blood. 2006;107(6):2279-2285.

21. Gramaglia I, et al. Low nitric oxide bioavailability contributes to the genesis of experimental cerebral malaria. Nat Med. 2006;12(12):1417-1422.

22. Baldwin C, et al. Association of klotho, bone morphogenic protein 6 , and annexin A2 polymorphisms with sickle cell osteonecrosis. Blood. 2005;106(1):372-375.

23. Bernaudin F, et al. G6PD deficiency, absence of alpha-thalassemia, and hemolytic rate at baseline are significant independent risk factors for abnormally high cerebral velocities in patients with sickle cell anemia. Blood.
2008;112(10):4314-4317.

24. Day TG, Drasar ER, Fulford T, Sharpe CC, Thein SL. Association between hemolysis and albuminuria in adults with sickle cell anemia. Haematologica. 2012;97(2):201-205.

25. Milton JN, et al. Genetic determinants of haemolysis in sickle cell anaemia. Br J Haematol. 2013;161(2):270-278.

26. Hamideh D, et al. Albuminuria correlates with hemolysis and NAG and KIM-1 in patients with sickle cell anemia. Pediatr Nephrol. 2014;29(10):1997-2003.

27. Miller ST, et al. Prediction of adverse outcomes in children with sickle cell disease. $N$ Engl J Med. 2000;342(2):83-89.

28. Quinn CT, Lee NJ, Shull EP, Ahmad N, Rogers ZR, Buchanan GR. Prediction of adverse outcomes in children with sickle cell anemia: a study of the Dallas Newborn Cohort. Blood. 2008;111(2):544-548.

29. Baum KF, Dunn DT, Maude GH, Serjeant GR. The painful crisis of homozygous sickle cell disease. A study of the risk factors. Arch Intern Med. 1987;147(7):1231-1234.

30. Akinsheye I, et al. Fetal hemoglobin in sickle cell anemia. Blood. 2011;118(1):19-27.

31. Castro O, et al. The acute chest syndrome in sickle cell disease: incidence and risk factors. The Cooperative Study of Sickle Cell Disease. Blood. 1994;84(2):643-649.

32. Bailey K, Morris JS, Thomas P, Serjeant GR. Fetal haemoglobin and early manifestations of homozygous sickle cell disease. Arch Dis Child. 1992;67(4):517-520.

33. Steinberg MH, Chui DH, Dover GJ, Sebastiani P, Alsultan A. Fetal hemoglobin in sickle cell anemia: a glass half full? Blood. 2014;123(4):481-485.

34. Franco RS, Yasin Z, Palascak MB, Ciraolo P, Joiner CH, Rucknagel DL. The effect of fetal hemoglobin on the survival characteristics of sickle cells. Blood. 2006;108(3):1073-1076.

35. De Ceulaer K, Higgs DR, Weatherall DJ, Hayes 
RJ, Serjeant BE, Serjeant GR. $\alpha$-Thalassemia reduces the hemolytic rate in homozygous sickle-cell disease [letter]. N Engl J Med. 1983;309(3):189-190.

36. Steinberg MH, Sebastiani P. Genetic modifiers of sickle cell disease. Am J Hematol. 2012;87(8):795-803.

37. Ataga KI, et al. Improvements in haemolysis and indicators of erythrocyte survival do not correlate with acute vaso-occlusive crises in patients with sickle cell disease: a phase III randomized, placebo-controlled, double-blind study of the Gardos channel blocker senicapoc (ICA-17043). Br J Haematol. 2011;153(1):92-104.

38. Minniti CP, et al. Anti-haemolytic effect of senicapoc and decrease in NT-proBNP in adults with sickle cell anaemia. Br J Haematol. 2011;155(5):634-636.

39. Machado RF, et al. N-terminal pro-brain natriuretic peptide levels and risk of death in sickle cell disease. JAMA. 2006;296(3):310-318.

40. Embury SH, Clark MR, Monroy G, Mohandas N. Concurrent sickle cell anemia and $\alpha$-thalassemia. Effect on pathological properties of sickle erythrocytes. J Clin Invest. 1984;73(1):116-123.

41. Ballas SK, Marcolina MJ. Hyperhemolysis during the evolution of uncomplicated acute painful episodes in patients with sickle cell anemia. Transfusion. 2006;46(1):105-110.

42. Taylor JG, Nolan VG, Mendelsohn L, Kato GJ, Gladwin MT, Steinberg MH. Chronic hyper-hemolysis in sickle cell anemia: association of vascular complications and mortality with less frequent vasoocclusive pain. PLoS One. 2008;3(5):e2095.

43. Guasch A, Zayas CF, Eckman JR, Muralidharan K, Zhang W, Elsas LJ. Evidence that microdeletions in the alpha globin gene protect against the development of sickle cell glomerulopathy in humans. JAm Soc Nephrol.1999;10(5):1014-1019.

44. Liem RI, Young LT, Thompson AA. Tricuspid regurgitant jet velocity is associated with hemolysis in children and young adults with sickle cell disease evaluated for pulmonary hypertension. Haematologica. 2007;92(11):1549-1552.

45. Saraf SL, et al. Haemoglobinuria is associated with chronic kidney disease and its progression in patients with sickle cell anaemia. Br J Haema tol. 2014;164(5):729-739.

46. Minniti CP, et al. Laboratory and echocardiography markers in sickle cell patients with leg ulcers. Am J Hematol. 2011;86(8):705-708.

47. Caughey MC, Poole C, Ataga KI, Hinderliter AL. Estimated pulmonary artery systolic pressure and sickle cell disease: a meta-analysis and systematic review. Br J Haematol. 2015;170(3):416-424.

48. Ataga KI, et al. Pulmonary hypertension in sickle cell disease. Am JMed. 2004;117(9):665-669.

49. Ataga KI, et al. Pulmonary hypertension in patients with sickle cell disease: a longitudinal study. Br J Haematol. 2006;134(1):109-115.

50. Naoman SG, et al. Echocardiographic findings in patients with sickle cell disease. Ann Hematol. 2010;89(1):61-66.

51. Gladwin MT, et al. Risk factors for death in 632 patients with sickle cell disease in the United States and United Kingdom. PLoS One. 2014;9(7):e99489.

52. Onyekwere OC, et al. Pulmonary hypertension in children and adolescents with sickle cell disease. Pediatr Cardiol. 2008;29(2):309-312.

53. van Beers EJ, et al. Cardiopulmonary imaging, functional and laboratory studies in sickle cell disease associated pulmonary hypertension. Am J Hematol. 2008;83(11):850-854.

54. Machado RF, Hildesheim M, Mendelsohn L, Remaley AT, Kato GJ, Gladwin MT. NT-pro brain natriuretic peptide levels and the risk of death in the cooperative study of sickle cell disease. $\mathrm{Br}$ Haematol. 2011;154(4):512-520.

55. Caughey MC, Hinderliter AL, Jones SK, Shah SP, Ataga KI. Hemodynamic characteristics and predictors of pulmonary hypertension in patients with sickle cell disease. Am J Cardiol. 2012;109(9):1353-1357.

56. Lee MT, Rosenzweig EB, Cairo MS. Pulmonary hypertension in sickle cell disease. Clin $\mathrm{Adv}$ Hematol Oncol. 2007;5(8):645-653.

57. Derchi G, et al. Prevalence and risk factors for pulmonary arterial hypertension in a large group of $\beta$-thalassemia patients using right heart catheterization: a Webthal study. Circulation. 2014;129(3):338-345.

58. Naik RP, Streiff MB, Haywood C Jr. Nelson JA, Lanzkron S. Venous thromboembolism in adults with sickle cell disease: a serious and under-recognized complication. Am J Med 2013;126(5):443-449.

59. Cappellini MD, Musallam KM, Taher AT. Insight onto the pathophysiology and clinical complications of thalassemia intermedia. Hemoglobin. 2009;33(suppl 1):S145-S159.

60. De Castro LM, Jonassaint JC, Graham FL, Ashley-Koch A, Telen MJ. Pulmonary hypertension associated with sickle cell disease: clinical and laboratory endpoints and disease outcomes. Am J Hematol. 2008;83(1):19-25.

61. Minniti CP, et al. Elevated tricuspid regurgitant jet velocity in children and adolescents with sickle cell disease: association with hemolysis and hemoglobin oxygen desaturation. Haematologica. 2009;94(3):340-347.

62. Voskaridou E, Tsetsos G, Tsoutsias A, Spyropoulou E, Christoulas D, Terpos E. Pulmonary hypertension in patients with sickle cell/beta thalassemia: incidence and correlation with serum $\mathrm{N}$-terminal pro-brain natriuretic peptide concentrations. Haematologica. 2007;92(6):738-743.

63. Damy T, et al. Haematological determinants of cardiac involvement in adults with sickle cell disease. Eur Heart J. 2016;37(14):1158-1167.

64. Mehari A, et al. Hemodynamic predictors of mortality in adults with sickle cell disease. Am J Respir Crit Care Med. 2013;187(8):840-847.

65. Parent F, et al. A hemodynamic study of pulmonary hypertension in sickle cell disease. $N$ Engl J Med. 2011;365(1):44-53

66. Fonseca GH, Souza R, Salemi VM, Jardim CV, Gualandro SF. Pulmonary hypertension diagnosed by right heart catheterisation in sickle cell disease. Eur Respir J. 2012;39(1):112-118.

67. Niss O, et al. Cardiomyopathy with restrictive physiology in sickle cell disease. JACC Cardiovasc Imaging. 2016;9(3):243-252.

68. Sachdev V, et al. Echocardiographic markers of elevated pulmonary pressure and left ventricular diastolic dysfunction are associated with exercise intolerance in adults and adolescents with homozygous sickle cell anemia in the United States and United Kingdom. Circulation. 2011;124(13):1452-1460.

69. Johnson MC, et al. Left ventricular hypertrophy and diastolic dysfunction in children with sickle cell disease are related to asleep and waking oxygen desaturation. Blood. 2010;116(1):16-21.

70. Dham N, et al. Prospective echocardiography assessment of pulmonary hypertension and its potential etiologies in children with sickle cell disease. Am J Cardiol. 2009;104(5):713-720.

71. Nolan VG, Wyszynski DF, Farrer LA, Steinberg MH. Hemolysis-associated priapism in sickle cell disease. Blood. 2005;106(9):3264-3267.

72. Lorch D, Spevack D, Little J. An elevated estimated pulmonary arterial systolic pressure, whenever measured, is associated with excess mortality in adults with sickle cell disease. Acta Haematol. 2011;125(4):225-229.

73. Forrest S, Kim A, Carbonella J, Pashankar F. Proteinuria is associated with elevated tricuspid regurgitant jet velocity in children with sickle cell disease. Pediatr Blood Cancer. 2012;58(6):937-940.

74. Anthi A, et al. Hemodynamic and functional assessment of patients with sickle cell disease and pulmonary hypertension. Am J Respir Crit Care Med. 2007;175(12):1272-1279.

75. Gordeuk VR, et al. Elevated tricuspid regurgitation velocity and decline in exercise capacity over 22 months of follow up in children and ado lescents with sickle cell anemia. Haematologica. 2011;96(1):33-40.

76. Mehari A, Gladwin MT, Tian X, Machado RF, Kato GJ. Mortality in adults with sickle cell disease and pulmonary hypertension. JAMA 2012;307(12):1254-1256.

77. D'Alonzo GE, et al. Survival in patients with primary pulmonary hypertension. Results from a national prospective registry. Ann Intern Med. 1991;115(5):343-349.

78. Hsu LL, et al. Hemolysis in sickle cell mice causes pulmonary hypertension due to global impairment in nitric oxide bioavailability. Blood. 2007;109(7):3088-3098.

79. Kaul DK, Liu XD, Chang HY, Nagel RL, Fabry ME. Effect of fetal hemoglobin on microvascular regulation in sickle transgenic-knockout mice. J Clin Invest. 2004;114(8):1136-1145.

80. Detterich JA, Kato RM, Rabai M, Meiselman HJ, Coates TD, Wood JC. Chronic transfusion therapy improves but does not normalize systemic and pulmonary vasculopathy in sickle cell disease. Blood. 2015;126(6):703-710.

81. Kaul DK, Liu XD, Fabry ME, Nagel RL. Impaired nitric oxide-mediated vasodilation in transgenic sickle mouse. Am J Physiol Heart Circ Physiol. 2000;278(6):H1799-H1806.

82. Hanson MS, et al. A novel hemoglobin-binding peptide reduces cell-free hemoglobin in murine hemolytic anemia. Am J Physiol Heart Circ Physiol. 2013;304(2):H328-H336.

83. Frei AC, et al. Vascular dysfunction in a murine model of severe hemolysis. Blood. 2008;112(2):398-405.

84. Vinchi F, et al. Hemopexin therapy improves cardiovascular function by preventing heme-induced endothelial toxicity in mouse 
models of hemolytic diseases. Circulation. 2013;127(12):1317-1329.

85. Hu W, et al. The critical roles of platelet activation and reduced NO bioavailability in fatal pulmonary arterial hypertension in a murine hemolysis model. Blood. 2010;116(9):1613-1622.

86. Minneci PC, et al. Hemolysis-associated endothelial dysfunction mediated by accelerated NO inactivation by decompartmentalized oxyhemoglobin. JClin Invest. 2005;115(12):3409-3417.

87. Tofovic SP, Jackson EK, Rafikova O. Adenosine deaminase-adenosine pathway in hemolysisassociated pulmonary hypertension. Med Hypotheses. 2009;72(6):713-719.

88. Yu B, Raher MJ, Volpato GP, Bloch KD, Ichinose F, Zapol WM. Inhaled nitric oxide enables artificial blood transfusion without hypertension. Circulation. 2008;117(15):1982-1990.

89. Donadee C, et al. Nitric oxide scavenging by red blood cell microparticles and cell-free hemoglobin as a mechanism for the red cell storage lesion. Circulation. 2011;124(4):465-476.

90. Berra L, et al. Autologous transfusion of stored red blood cells increases pulmonary artery pressure. Am J Respir Crit Care Med. 2014;190(7):800-807.

91. Schaer CA, et al. Haptoglobin preserves vascular nitric oxide signaling during hemolysis. $A m \mathrm{~J}$ Respir Crit Care Med. 2016;193(10):1111-1122.

92. Almeida CB, et al. Acute hemolytic vascular inflammatory processes are prevented by nitric oxide replacement or a single dose of hydroxyurea. Blood. 2015;126(6):711-720.

93. Yu B, Lei C, Baron DM, Steinbicker AU, Bloch KD, Zapol WM. Diabetes augments and inhaled nitric oxide prevents the adverse hemodynamic effects of transfusing syngeneic stored blood in mice. Transfusion. 2012;52(7):1410-1422.

94. Lei C, Yu B, Shahid M, Beloiartsev A, Bloch KD, Zapol WM. Inhaled nitric oxide attenuates the adverse effects of transfusing stored syngeneic erythrocytes in mice with endothelial dysfunction after hemorrhagic shock. Anesthesiology. 2012;117(6):1190-1202.

95. Risbano MG, et al. Effects of aged stored autologous red blood cells on human endothelial function. Am J Respir Crit Care Med. 2015;192(10):1223-1233.

96. Baek JH, et al. Hemoglobin-driven pathophysiology is an in vivo consequence of the red blood cell storage lesion that can be attenuated in guinea pigs by haptoglobin therapy. J Clin Invest. 2012;122(4):1444-1458.

97. Yeo TW, et al. Impaired nitric oxide bioavailability and L-arginine reversible endothelial dysfunction in adults with falciparum malaria. J Exp Med. 2007;204(11):2693-2704.

98. Yeo TW, et al. Relationship of cell-free hemoglobin to impaired endothelial nitric oxide bioavailability and perfusion in severe falciparum malaria. JInfect Dis. 2009;200(10):1522-1529.

99. Janka JJ, et al. Increased pulmonary pressures and myocardial wall stress in children with severe malaria. JInfect Dis. 2010;202(5):791-800.

100.Vinchi F, Tolosano E. Therapeutic approaches to limit hemolysis-driven endothelial dysfunction: scavenging free heme to preserve vasculature homeostasis. Oxid Med Cell Longev.
2013;2013:396527.

101.Serghides L, et al. Inhaled nitric oxide reduces endothelial activation and parasite accumulation in the brain, and enhances survival in experimental cerebral malaria. PLoS One. 2011;6(11):e27714.

102. Soares MP, Bozza MT. Red alert: labile heme is an alarmin. Curr Opin Immunol. 2016;38:94-100.

103. Roumenina LT, Rayes J, Lacroix-Desmazes S, Dimitrov JD. Heme: Modulator of plasma systems in hemolytic diseases. Trends Mol Med. 2016;22(3):200-213.

104.Ghosh S, et al. Extracellular hemin crisis triggers acute chest syndrome in sickle mice. JClin Invest. 2013;123(11):4809-4820.

105. Belcher JD, et al. Heme triggers TLR4 signaling leading to endothelial cell activation and vaso-occlusion in murine sickle cell disease. Blood. 2014;123(3):377-390.

106. Vercellotti GM, et al. Hepatic overexpression of hemopexin inhibits inflammation and vascular stasis in murine models of Sickle Cell disease. Mol Med. 2016;22:437-451.

107. Vinchi F, et al. Hemopexin therapy reverts heme-induced proinflammatory phenotypic switching of macrophages in a mouse model of sickle cell disease. Blood. 2016;127(4):473-486.

108.Sparkenbaugh EM, et al. Excess of heme induces tissue factor-dependent activation of coagulation in mice. Haematologica. 2015;100(3):308-314.

109. Chen G, Zhang D, Fuchs TA, Manwani D, Wagner DD, Frenette PS. Heme-induced neutrophil extracellular traps contribute to the pathogenesis of sickle cell disease. Blood. 2014;123(24):3818-3827.

110.Wang X, et al. Heme-bound iron activates placenta growth factor in erythroid cells via erythroid Krüppel-like factor. Blood. 2014;124(6):946-954.

111. Sundaram N, et al. High levels of placenta growth factor in sickle cell disease promote pulmonary hypertension. Blood. 2010;116(1):109-112.

112. Reiter CD, et al. Cell-free hemoglobin limits nitric oxide bioavailability in sickle-cell disease. Nat Med. 2002;8(12):1383-1389.

113. Wood KC, Granger DN. Sickle cell disease: role of reactive oxygen and nitrogen metabolites. Clin Exp Pharmacol Physiol. 2007;34(9):926-932.

114. Hebbel RP. The sickle erythrocyte in double jeopardy: autoxidation and iron decompartmentalization. Semin Hematol. 1990;27(1):51-69.

115. Aufradet E, et al. Hypoxia/reoxygenation stress increases markers of vaso-occlusive crisis in sickle SAD mice. Clin Hemorheol Microcirc. 2013;54(3):297-312.

116. Belcher JD, Beckman JD, Balla G, Balla J, Vercellotti G. Heme degradation and vascular injury. Antioxid Redox Signal. 2010;12(2):233-248.

117. Aslan M, Thornley-Brown D, Freeman BA. Reactive species in sickle cell disease. Ann N Y Acad Sci. 2000;899:375-391.

118. Repka T, Hebbel RP. Hydroxyl radical formation by sickle erythrocyte membranes: role of pathologic iron deposits and cytoplasmic reducing agents. Blood. 1991;78(10):2753-2758.

119. Reeder BJ. The redox activity of hemoglobins: from physiologic functions to pathologic mechanisms. Antioxid Redox Signal. 2010;13(7):1087-1123.

120. Cyrklaff M, et al. Hemoglobins S and C interfere with actin remodeling in Plasmodium falciparum-infected erythrocytes. Science.
2011;334(6060):1283-1286.

121. Kassa T, et al. Sickle Cell Hemoglobin in the ferryl state promotes $\beta$ Cys-93 oxidation and mitochondrial dysfunction in epithelial lung cells (E10). J Biol Chem. 2015;290(46):27939-27958.

122. Hebbel RP, Key NS. Microparticles in sickle cell anaemia: promise and pitfalls. Br J Haematol. 2016;174(1):16-29.

123. Camus SM, et al. Circulating cell membrane microparticles transfer heme to endothelial cells and trigger vasoocclusions in sickle cell disease. Blood. 2015;125(24):3805-3814.

124.van Beers EJ, et al. Iron, inflammation, and early death in adults with sickle cell disease. Circ Res. 2015;116(2):298-306.

125. Dutra FF, et al. Hemolysis-induced lethality involves inflammasome activation by heme. Proc Natl Acad Sci U S A. 2014;111(39):E4110-E4118.

126. Gladwin MT, Ofori-Acquah SF. Erythroid DAMPs drive inflammation in SCD. Blood. 2014;123(24):3689-3690.

127. Mendonça R, Silveira AA, Conran N. Red cell DAMPs and inflammation. Inflamm Res. 2016;65(9):665-678.

128. Cardenes N, et al. Platelet bioenergetic screen in sickle cell patients reveals mitochondrial complex V inhibition, which contributes to platelet activation. Blood. 2014;123(18):2864-2872.

129. Kato GJ. TRV: a physiological biomarker in sickle cell disease. Pediatr Blood Cancer. 2012;58(6):831-832.

130. Upadhya B, Stacey RB, Ntim W, Knovich MA, Pu M. Echocardiography-derived tricuspid regurgitant jet velocity is an important marker for the progression of sickle-cell disease. Acta Haematol. 2014;132(2):152-158.

131. Nguyen KL, et al. Elevated transpulmonary gradient and cardiac magnetic resonancederived right ventricular remodeling predict poor outcomes in sickle cell disease. Haematologica. 2016;101(2):e40-e43.

132. Bakeer N, et al. Sickle cell anemia mice develop a unique cardiomyopathy with restrictive physiology. Proc Natl Acad Sci U S A. 2016;113(35):E5182-E5191.

133. Quinn CT, et al. Biochemical surrogate markers of hemolysis do not correlate with directly measured erythrocyte survival in sickle cell anemia. Am J Hematol. 2016;91(12):1195-1201.

134. Jison ML, et al. Blood mononuclear cell gene expression profiles characterize the oxidant, hemolytic, and inflammatory stress of sickle cell disease. Blood. 2004;104(1):270-280.

135. Belcher JD, et al. Low-density lipoprotein susceptibility to oxidation and cytotoxicity to endothelium in sickle cell anemia. J Lab Clin Med. 1999;133(6):605-612.

136. Yuditskaya S, et al. Proteomic identification of altered apolipoprotein patterns in pulmonary hypertension and vasculopathy of sickle cell disease. Blood. 2009;113(5):1122-1128.

137. Zorca S, et al. Lipid levels in sickle-cell disease associated with haemolytic severity, vascular dysfunction and pulmonary hypertension. $\mathrm{Br} J$ Haematol. 2010;149(3):436-445.

138. Ataga KI, et al. Association of pro-inflammatory high-density lipoprotein cholesterol with clinica and laboratory variables in sickle cell disease. 
Hematology. 2015;20(5):289-296.

139. Nouraie M, et al. The relationship between the severity of hemolysis, clinical manifestations and risk of death in 415 patients with sickle cell anemia in the US and Europe. Haematologica. 2013;98(3):464-472.

140. Brittain JE, et al. Placenta growth factor in sickle cell disease: association with hemolysis and inflammation. Blood.2010;115(10):2014-2020.

141. Ataga KI, et al. Albuminuria is associated with endothelial dysfunction and elevated plasma endothelin-1 in Sickle Cell anemia. PLoS One. 2016;11(9):e0162652.

142. Heimlich JB, et al. Endothelin-1 contributes to the progression of renal injury in sickle cell disease via reactive oxygen species. Br J Pharmacol. 2016;173(2):386-395.

143. Sabaa N, et al. Endothelin receptor antagonism prevents hypoxia-induced mortality and morbidity in a mouse model of sickle-cell disease. JClin Invest. 2008;118(5):1924-1933.

144.Crosby WH. The metabolism of hemoglobin and bile pigment in hemolytic disease. Am J Med. 1955;18(1):112-122.

145. Bean CJ, et al. Heme oxygenase-1 gene promoter polymorphism is associated with reduced incidence of acute chest syndrome among children with sickle cell disease. Blood. 2012;120(18):3822-3828.

146.Ghosh S, et al. Nonhematopoietic Nrf2 dominantly impedes adult progression of sickle cell anemia in mice. JCI Insight. 2016;1(4):e81090.

147. Doss JF, Jonassaint JC, Garrett ME, AshleyKoch AE, Telen MJ, Chi JT. Phase 1 study of a sulforaphane-containing broccoli sprout homogenate for sickle cell disease. PLoS One. 2016;11(4):e0152895.

148. Machado RF, et al. Hospitalization for pain in patients with sickle cell disease treated with sildenafil for elevated TRV and low exercise capacity. Blood. 2011;118(4):855-864

149. Gladwin MT, et al. Nitric oxide donor properties of hydroxyurea in patients with sickle cell disease. Br J Haematol. 2002;116(2):436-444.

150. Gladwin MT, Kania T, Kim-Shapiro DB. Hemolysis and cell-free hemoglobin drive an intrinsic mechanism for human disease. JClin Invest. 2012;122(4):1205-1208.

151. Darbari DS, et al. Markers of severe vaso-occlusive painful episode frequency in children and adolescents with sickle cell anemia. J Pediatr. 2012;160(2):286-290.

152. Gill FM, et al. Clinical events in the first decade in a cohort of infants with sickle cell disease. Cooperative Study of Sickle Cell Disease. Blood. 1995;86(2):776-783.

153. Cumming V, King L, Fraser R, Serjeant G, Reid $\mathrm{M}$. Venous incompetence, poverty and lactate dehydrogenase in Jamaica are important predictors of leg ulceration in sickle cell anaemia. $\mathrm{Br} \mathrm{J}$ Haematol. 2008;142(1):119-125.

154. Koshy M, et al. Leg ulcers in patients with sickle cell disease. Blood. 1989;74(4):1403-1408.

155. Milner PF, et al. Sickle cell disease as a cause of osteonecrosis of the femoral head. N Engl J Med. 1991;325(21):1476-1481.
156. Powars DR, Chan L, Schroeder WA. The influence of fetal hemoglobin on the clinical expression of sickle cell anemia. Ann N Y Acad Sci. 1989;565:262-278.

157. Hawker H, Neilson H, Hayes RJ, Serjeant GR. Haematological factors associated with avascular necrosis of the femoral head in homozygous sickle cell disease. Br J Haematol. 1982;50(1):29-34.

158. Mahadeo KM, et al. Increased prevalence of osteonecrosis of the femoral head in children and adolescents with sickle-cell disease. Am J Hematol. 2011;86(9):806-808.

159. Diop S, et al. [Predictive factors of chronic complications in adult sickle cell anemia patients in Dakar, Senegal] (article in French). Med Trop (Mars). 2010;70(5-6):471-474.

160.Mukisi-Mukaza M, et al. Prevalence, clinical features, and risk factors of osteonecrosis of the femoral head among adults with sickle cell disease. Orthopedics. 2000;23(4):357-363.

161. Adekile AD. Limitations of $\mathrm{Hb} F$ as a phenotypic modifier in sickle cell disease: study of Kuwaiti Arab patients. Hemoglobin. 2011;35(5-6):607-617.

162. Emond AM, Holman R, Hayes RJ, Serjeant GR. Priapism and impotence in homozygous sickle cell disease. Arch Intern Med. 1980;140(11):1434-1437.

163. Nebor $\mathrm{D}$, et al. $\alpha$-Thalassemia is associated with a decreased occurrence and a delayed age-at-onset of albuminuria in sickle cell anemia patients. Blood Cells Mol Dis. 2010;45(2):154-158.

164. Haymann JP, et al. Glomerular hyperfiltration in adult sickle cell anemia: a frequent hemolysis associated feature. Clin J Am Soc Nephrol. 2010;5(5):756-761.

165. Ware RE, et al. Renal function in infants with sickle cell anemia: baseline data from the BABY HUG trial. J Pediatr. 2010;156(1):66-70.e1.

166. Powars DR, et al. Chronic renal failure in sickle cell disease: risk factors, clinical course, and mortality. Ann Intern Med. 1991;115(8):614-620.

167. Wigfall DR, Ware RE, Burchinal MR, Kinney TR, Foreman JW. Prevalence and clinical correlates of glomerulopathy in children with sickle cell disease. J Pediatr. 2000;136(6):749-753.

168. Becton LJ, et al. Prevalence and clinical correlates of microalbuminuria in children with sickle cell disease. Pediatr Nephrol. 2010;25(8):1505-1511.

169.King L, MooSang M, Miller M, Reid M. Prevalence and predictors of microalbuminuria in Jamaican children with sickle cell disease. Arch Dis Child. 2011;96(12):1135-1139.

170. Joly P, et al. G6PD deficiency and absence of $\alpha$-thalassemia increase the risk for cerebral vasculopathy in children with sickle cell anemia. Eur JHaematol. 2016;96(4):404-408.

171. Belisário AR, et al. Association of alpha-thalassemia, TNF- $\alpha(-308 \mathrm{G}>\mathrm{A})$ and VCAM- 1 (c.1238G $>$ C) gene polymorphisms with cerebrovascular disease in a newborn cohort of 411 children with sickle cell anemia. Blood Cells Mol Dis. 2015;54(1):44-50

172. Cox SE, et al. Haptoglobin, alpha-thalassaemia and glucose-6-phosphate dehydrogenase polymorphisms and risk of abnormal transcranial Doppler among patients with sickle cell anaemia in Tanzania. Br J Haematol. 2014;165(5):699-706
173. Ohene-Frempong K, et al. Cerebrovascular accidents in sickle cell disease: rates and risk factors. Blood.1998;91(1):288-294.

174. Kinney TR, et al. Silent cerebral infarcts in sickle cell anemia: a risk factor analysis. The Cooperative Study of Sickle Cell Disease. Pediatrics. 1999;103(3):640-645.

175. Kwiatkowski JL, et al. Silent infarcts in young children with sickle cell disease. Br J Haematol. 2009;146(3):300-305.

176. Hsu LL, et al. $\alpha$-Thalassemia is associated with decreased risk of abnormal transcranial Doppler ultrasonography in children with sickle cell anemia. J Pediatr Hematol Oncol. 2003;25(8):622-628

177. Wang WC, et al. MRI abnormalities of the brain in one-year-old children with sickle cell anemia. Pediatr Blood Cancer. 2008;51(5):643-646.

178. Mikobi TM, et al. Correlation between the lactate dehydrogenase levels with laboratory variables in the clinical severity of sickle cell anemia in Congolese patients. PLoS One. 2015;10(5):e0123568.

179. Hamad Z, Aljedai A, Halwani R, AlSultan A. UGT1A1 promoter polymorphism associated with serum bilirubin level in Saudi patients with sickle cell disease. Ann Saudi Med. 2013;33(4):372-376.

180. Wali YA, et al. Splenic function in Omani children with sickle cell disease: correlation with severity index, hemoglobin phenotype, iron status, and alpha-thalassemia trait. Pediatr Hematol Oncol. 2002;19(7):491-500.

181. Vasavda N, et al. The linear effects of alpha-thalassaemia, the UGT1A1 and HMOX1 polymorphisms on cholelithiasis in sickle cell disease. Br J Haematol. 2007;138(2):263-270.

182.Webb DK, Darby JS, Dunn DT, Terry SI, Serjeant GR. Gall stones in Jamaican children with homozygous sickle cell disease. Arch Dis Child. 1989;64(5):693-696.

183. Fox PD, Higgs DR, Serjeant GR. Influence of $\alpha$-thalassemia on the retinopathy of homozygous sickle-cell disease. Br JOphthalmol. 1993;77(2):89-90.

184.Condon PI, Marsh RJ, Maude GH, Higgs DR, Weatherall DJ, Serjeant GR. $\alpha$-Thalassemia and the macular vasculature in homozygous sickle cell disease. Br JOphthalmol. 1983;67(11):779-781.

185. Talbot JF, Bird AC, Rabb LM, Maude GH, Serjeant GR. Sickle cell retinopathy in Jamaican children: a search for prognostic factors. $\mathrm{Br} J$ Ophthalmol. 1983;67(11):782-785.

186. Taylor JG, et al. Mutations and polymorphisms in hemoglobin genes and the risk of pulmonary hypertension and death in sickle cell disease. $A m$ JHematol. 2008;83(1):6-14

187. Gordeuk VR, et al. Relationship of erythropoietin, fetal hemoglobin, and hydroxyurea treatment to tricuspid regurgitation velocity in children with sickle cell disease. Blood. 2009;114(21):4639-4644.

188. Barbedo MM, McCurdy PR. Red cell life span in sickle cell trait. Acta Haematol. 1974;51(6):339-343.

189. Mears JG, Lachman HM, Labie D, Nagel RL. Alpha-thalassemia is related to prolonged survival in sickle cell anemia. Blood.1983;62(2):286-290.

190. Platt OS, et al. Mortality in sickle cell disease. Life expectancy and risk factors for early death. N Engl JMed.1994;330(23):1639-1644. 